\title{
The need to include obstetric nurses in prenatal care visits in the public health system
}

\author{
A necessidade de inserção do enfermeiro obstetra na realização de consultas de pré-natal na \\ rede pública
}

\author{
Selma Aparecida Lagrosa Garcia ${ }^{1}$, Sidney Antonio Lagrosa Garcia ${ }^{2}$, Umberto Gazi Lippi ${ }^{3}$
}

\begin{abstract}
Objective: To investigate, with a qualitative approach, the role of Obstetric Nurses at the primary level of care given to women's health as a vital component of the multidisciplinary team, which today is fundamental for providing care, prevention as well as health education and promotion, especially in programs whose activities are geared towards primary care of pregnant, parturient, and puerpera women. Methods: Brazilian laws and the determinations of Nursing Councils in reference to the activities of the obstetric nurse were researched, including the nurse's responsibilities and limits. The bibliographic search was conducted in health-related journals, lay publications, and the Internet. Results: The conflicts between professional physicians and nurses were discussed. Conclusions: It was concluded that the activities of the nurse, conducting low-risk prenatal clinical visits in the basic healthcare network, has legal and ethical support and provides true benefit to the clients.
\end{abstract}

Keywords: Obstetrical nursing; Nurse's role; Prenatal care; Public assistance

\section{RESUMO}

Objetivo: Pesquisar com abordagem qualitativa o papel da atuação do Enfermeiro Obstetra no nível primário de atenção à saúde da mulher, como componente importante da equipe multidisciplinar, hoje fundamental para o acolhimento, educação, prevenção e promoção em saúde, particularmente nos programas em que a ação se refere ao atendimento primário, cujo exemplo marcante é a atenção à gestante, parturiente e puérpera. Métodos: Pesquisaram-se as leis brasileiras e as determinações dos Conselhos de Enfermagem referentes à atuação do enfermeiro obstetra, suas competências e limites. A pesquisa bibliográfica foi feita em revistas da área de saúde, publicações leigas escritas e na internet. Resultados: Discutiram-se os conflitos entre profissionais médicos e enfermeiros. Conclusões: Conclui-se que a atuação do enfermeiro, realizando consultas de pré-natal de baixo risco na rede básica de saúde, tem amparo legal e ético, com real benefício à clientela.

Descritores: Enfermagem obstétrica; Papel do profissional de enfermagem; Cuidado pré-natal; Assistência pública

\section{INTRODUCTION}

Health is a factor of fundamental importance to the human being, and it is necessary for the State and society to continually seek policies to regulate the system that supports healthcare. By means of the Brazilian National Healthcare System (SUS, acronym in Portuguese for Unified Health System), innovative procedures have been adopted as of 1990, when two by-laws, which are now in the constitutional regulatory phase, were edited. Law 8.080, dated September 19, 1990 - considered the By-Law of Healthcare - and law 8.142, dated December 28, 1990, which addresses, among other topics, the participation of the community in management of SUS. Later, in 1994, the Family Healthcare Program (PSF, acronym in Portuguese) was created with a strategy for consolidation that occurred in 1998. The program is structured in a partnership with the State Secretariats of Health, Municipalities, and Upper Level Educational Institutions, and it aims to affect primarily the poorest strata of society.

It functions by means of a Family Healthcare Unit, with a multi-professional team made up of one physician, one nurse, one nurse's aide, and community healthcare agents.

\footnotetext{
'Postgraduate degree at Instituto de Assistência Medica ao Servidor Público Estadual - IAMSPE - São Paulo (SP), Brazil; Nurse at Prefeitura Municipal de Itapevi, Itapevi (SP), Brazil.

${ }^{2}$ Master's degree; MD at Hospital do Servidor Público Estadual "Francisco Morato de Oliveira" - HSPE-FMO, São Paulo (SP), Brazil.

${ }^{3}$ PhD; MD at Hospital do Servidor Público Estadual "Francisco Morato de Oliveira" - HSPE-FMO, São Paulo (SP), Brazil.

Corresponding author: Selma Aparecida Lagrosa Garcia - Estrada da Aldeia, 451, casa 164 - Granja Viana Cotia - CEP 06709-300 - São Paulo (SP), Brasil - Tel.: 11 4617-5411 - e-mail: selmaobst@terra.com.br

Received on Sep 3, 2009 - Accepted on Apr 12, 2010
} 
This program has provided to a large part of society, which lives in a situation of social exclusion, greater access to healthcare. In prenatal care, it is fundamental for preparation for maternity, and has been considered, among other things, as a preventive effort. On the other hand, it makes the nurse play a preponderant role, from planning of actions to healthcare itself, which makes his/her activity different from those performed in traditionally structured institutions.

Many discussions have occurred as to the role played by the obstetric nurse in the PSF, which vary from a lack of definition of roles and of social prestige, to lack of autonomy.

By Nursing Consultation/Visit, one understands the act of consulting or requesting advice, opinion, or guidance. This procedure is a relationship for providing help and a learning situation between the client and the nurse, in search of a solution for problems that have been identified in the patient's well-being. It is the nurse's responsibility to provide care to the individual, the family, and the community in a systematic and continuous manner, with the purpose of promoting health by means of early diagnosis. The advantages of prenatal care given at the PSF by the professionals specialized in obstetrics are noteworthy. Nevertheless, it is evident that technical capacity is not sufficient for adequate performance of the activities intended, since many variables that imply success in prenatal care are not the responsibility of the professional nurse. One of the problems encountered is the difficulty to carry out examinations/tests that require better resources, such as ultrasonography, which is currently a routine in prenatal care. Another problem faced is the number of consultations during pregnancy, which is frequently lower than what would be ideal for a good maternal-fetal follow-up during gestation.

Additionally, there are conflicts between doctors and nurses as to their autonomy, attributes, and responsibilities.

If the obstetric nurse has the qualities needed to help during labor, i.e., technical training, knowledge as to gestation, delivery, and puerperium, he/she is legally prepared to conduct diagnoses, prescribe medications, and order and evaluate tests.

\section{OBJECTIVE}

To demonstrate the need for the Obstetric Nurse as a fundamental component in prenatal and puerperium activities in the basic healthcare network, providing prenatal consultations to low-risk patients of the Primary Healthcare Units (UBS, acronym in Portuguese).

\section{METHODS}

The present study consists of a bibliographic investigation of the PSF and of the activities of obstetric nurses, as well as of what legislation determines as to responsibilities, limits, and ethical and legal demands in giving prenatal assistance. Studies in healthcare published in scientific literature were researched using database Lilacs, Laws of Brazil, and resolutions of Nursing Councils, publications in non-indexed periodicals, besides lay publications and all that is available on the Internet.

\section{RESULTS}

\section{Short history of nursing}

Nursing in ancient times relied on human solidarity, mysticism, common sense, and superstitions in the midst of the primitive tribal community, expressed through the instinctive act of "taking care of", which was a guarantee of preserving one's own species. Currently, this profession seeks to deepen its scientific, technological, and humanistic aspects, having at the core of its activities the care of the human being. Nursing began through empirical knowledge, acquired its scientific basis as of the early $20^{\text {th }}$ century, and seeks to rid itself of the stereotype of an inferior profession, as described by Geovanini et al. ${ }^{(1)}$. It was institutionalized in England during the $19^{\text {th }}$ century through Florence Nightingale, the precursor of modern nursing (1860) who recommended care of hospitalized patients, contemplating concepts of cleanliness, tending to the patient's basic needs, and guidance of family members as to health-related issues. The professional training, in these conditions, would come to involve technical courses supported by scientific knowledge. In Brazil, nursing was in the hands of Charity Sisters and laypersons (expatients and servants in hospitals), almost exclusively at the mercy of the empiricism of both, forged quotidian in the routines of Santa Casa de Misericórdia ${ }^{(2,3)}$.

For Vargens, "Nursing went from a role played by lay and religious persons with no specific training, to a profession with a college education integrated with the university, with various options of graduate studies, i.e., which has accompanied the course of scientificism and academia of other professions. Research in nursing developed, and many specialties have arisen as technology has mandated them." ${ }^{(4)}$.

Over the years, nursing came to be recognized as a profession; class entities were born with the primordial purpose of congregating nurses and nurse technicians and encouraging a spirit of union and solidarity among the classes, as defined by the Brazilian Association of Nursing (ABEn). 


\section{Short history of nursing schools in Brazil}

Anna Nery (1814-1880), a nurse, played the role of Nightingale in Brazil, breaking away from the image of women as prisoners of their homes. In 1890, the "Alfredo Pinto" School of Nursing was born in Rio de Janeiro, with a 3-year course directed by graduate nurses. In 1895, the School of Nursing of the Hospital Samaritano, with English schoolmasters, was initiated. Also, the activities of the Red Cross Course of [Lay] Rescuers of Rio de Janeiro began. In 1923, the Ana Nery School was founded. In 1933, the State began the "Carlos Chagas" School of Nursing. The Escola Paulista de Enfermagem began in 1939, and the School of Nursing of the University of São Paulo, in 1942.

In 1955 , the law $\mathrm{n}^{\circ} 2604$ was promulgated, regulating the activities of professional nurses. Nurses' training was promoted to the upper level of schooling. The creation of Federal and Regional Councils of Nurses occurred by means of law $\mathrm{n}^{\circ} 5905$, dating from 1973 . The Regional Council of Nursing of São Paulo was inaugurated in $1975^{(5)}$.

\section{Midwifery schools, and qualification and specialization in obstetric nursing}

As a pool of tocology practices, obstetrics originated in the knowledge accrued by midwives, with predominantly female participation. According to Ziegael and Cranley, the practice of obstetric nursing, as that of any other profession, is substantially influenced by numerous factors within the profession itself and society in general $^{(6)}$. The professionalization of midwives occurred through the creation of the course by the School of Medicine, between 1832 and 1834, and the graduation of the first midwife with a diploma, Madame Durocher. In Brazil, in 1832 the first courses for training midwives operated together with the only two Medical Schools in existence then - in Rio de Janeiro and in Bahia - which controlled midwife training until the middle of the $20^{\text {th }}$ century. The first legal document on the teaching of midwives is dated 1832, when the Medical-Surgical Academies of Rio de Janeiro and Bahia, transformed into Schools of Medicine, included the two-year Labor/ Birthing Courses. At the end of the $19^{\text {th }}$ century, there was a decline in midwifery as the medical paradigm was established in which care given at the moment of labor and birth is strictly interventionalist, surgical. From then on, the nursing professional went through various designations: midwife, obstetriz. and obstetric nurse, reflecting the inconstant nature of the profession during the last few years ${ }^{(7)}$.

"Midwife" is the oldest title of this profession which was posteriorly denominated obstetric nurse and obstetriz. Obstetric nurse is the most recent title, and it consolidates the training of a nurse (noun), modified by the adjective, obstetric, as per the title of specialist in that area. Although these terms may seem to be nuances of little importance, they translate modifications in legislation regarding teaching and the concept as to the modality of training and of the profession itself $f^{(8)}$.

Initially, aid to pregnant women was given by midwives, women who learned their trade by experience, usually by helping older midwives. Active in the northern, northeastern, and Midwestern regions [of Brazil], they are responsible for home deliveries, especially in rural regions where access to hospitals is difficult. The next term to be used was Obstetrizes, professionals trained by means of a specific technical course. That course was extinguished, and today only midwives who were trained before the 1970s are active in the profession. Responsible for low-risk deliveries, both in homes and in hospitals or at "birthing centers", their functions are similar to those of Obstetric Nurses. Finally, Obstetric Nurses are nurses with college degrees and specialization in the area of Obstetrics. They are qualified to provide prenatal care, deliveries with no dystocia, and puerperium care. As of 1949, schools of nursing began to officially train obstetric nurses; the professional who had a nursing diploma could attend the Specialization Course in Obstetric Nursing and, at the end of one year, receive a certificate of obstetric nurse.

\section{Legislation of the activity of the obstetric nurse}

The legal exercise of recognized professions, which determines the judicial and ethical responsibilities and limits, should be regulated by legal texts. In this way, the knowledge of these texts is of fundamental importance. These laws are explained below.

A-Lawn ${ }^{\circ} 8.967 / 94$, Dec.n $^{\circ}$ 94.406/87(Regulamentation), in its Art. No. 9, defines what midwives are;

B-Law n ${ }^{\circ}$.498, dated June 25, 1986, updates regulations on the profession of midwives with diplomas issued by foreign schools;

C-Official Notice $n^{\circ} 2.815$, dated May 29, 1998, includes in the Table of the Hospital Information System of the Unified National Healthcare System normal deliveries with no dystocia performed by an obstetric nurse.

D - Normative Resolution $\mathrm{n}^{\circ} 167$, dated January 9, 2007, updates the List of Procedures and Events in Healthcare, which constitutes the basic reference for health insurance coverage in private healthcare plans; contracted as of January $1^{\text {st }}$, 1999, it establishes the directives of Healthcare and gives other guidance: 
"Single Paragraph: for the purposes of coverage of a natural delivery listed in Annex I, this procedure may be conducted by an Obstetric Nurse, certified according to the attributes defined by Law $\mathrm{n}^{\circ} 7.498$, dated June 25,1986 , which rules the professional exercise of the profession of Nursing, regulated by Decree $\mathrm{n}^{\circ}$ 94.406, dated June 8, 1987, as is set forth in Article 5 of this Normative Resolution."

The Ministry of Health* recommends attributes for each member of this Family Healthcare Team, in which the Nurse carries out direct nursing care, making the referral for continuity of the nursing care given; nursing consultation/visit, ordering ancillary tests, prescribing/transcribing medications; planning, managing, coordinating, executing, and evaluating the USF; supervising and coordinating the actions of the Community Healthcare Agents and of Licensed Practical Nurses (LPNs).

The Law $n^{\circ} 7498$, dated June 25, 1986, that regulates the exercise of nursing in Brazil, is clear and guarantees the rights of all those who make up the nursing class (Art. 1). The following are topics relevant to the practice of nursing in the PSF: nursing consultation/ visit, performed by the nurse in all its complexity (Art. 11, subheading i); prescription of medications, as long as these are established in Public Health programs and in routines approved by the healthcare institution (Art. 11, subheading c); the exercise of nursing by professionals of technical and elementary level, under the supervision of a nurse (Art. 15).

\section{Rules and regulations of the activities of the obstetric nurse as per COFEN}

The Resolution $\mathrm{n}^{\circ} 195$, by the Federal Council of Nursing (COFEN, Portuguese acronym), from 1997, in reference to the legality of ordering routine ancillary tests by the nurse, is emphatic in affirming, in its Art. 1: "the nurse may order routine and ancillary tests when exercising his/her professional activities". Thus, once again, the right of nurses to request routine and supplementary tests is guaranteed.

COFEN Resolution $n^{\circ} 223$, from 1999, establishes in its Art. 3 the responsibilities of the obstetric nurse: a) assistance to the parturient and normal deliveries; b) identification of obstetric dystocias and provision for all necessary actions until the arrival of the physician, with the responsibility of intervening, according to his/her technical-scientific training, adopting the procedures he/she considers obligatory in order to guarantee safety to mother and child; c) performance of episiotomy, episiorrhaphia, and application of local anesthesia when appropriate; d) emission of the Nurse's Report for Hospital Admission Authorization, which is provided in the annex of the Official Notice SAS/MS-163/98; e) follow-up of the client under his/her care, from hospital admission to discharge.

On August 30, 2000, COFEN Resolution 240 went into effect, in which Chapter III, "Of responsibilities", postulates that the nurse has the responsibility to assure quality nursing care, guaranteeing the patient's physical integrity, and it also establishes that the nurse should only execute a given procedure after careful analysis of his/her technical and legal competence, as the nurse should constantly seek to update his/her knowledge in order to improve the quality of services offered.

CNE/CES Resolution $\mathrm{n}^{\circ}$ 3, from November 2001, institutes the National Curricular Directives for undergraduate nursing courses, which should be followed in the reformulation of a minimum curriculum in Brazil.

COFEN Resolution $n^{\circ}$ 271, from 2002, regulates the nursing consultation/visit, diagnosis of pathologies, requests for routine and supplementary tests, among other things. This legal provision allows the nurse to execute the actions mentioned above, but maintains the legal limits foreseen in law $n^{\circ} 7498 / 86$ and in Presidential Decree $n^{\circ} 94406 / 87$. These limits are the programs of Public Healthcare and the routines approved by public or private healthcare.

\section{Conflicts of competence and responsibility between the physician and the obstetric nurse}

Based on what was exposed as to legal and ethical texts that rule the activities and limitations of the obstetric nurse, it is clear that conducting low-risk prenatal consultations, in the same way as the clinical visits associated with puerperium, may and should be performed by this professional at the primary level of healthcare, i.e., in the UBS.

This type of care has been given but still in a suboptimal manner, for various reasons. In the research carried out, we identified documentation of the activity of the obstetric nurse in low-risk prenatal care visits. As an example, we mention the Prenatal Care Program of the Municipal Healthcare Center of Jardim Peabirú (SP) $)^{* *}$, as follows:

"This Program (since 1992) seeks to provide to low-risk pregnant women, who reside in the

\footnotetext{
* Brasil. Ministério da Saúde. Secretaria de Políticas da Saúde. Guia prático do Programa Saúde da Família. Brasília, DF: MS; 2001

** Exposed by Cristina Maria Garcia de Lima Parada, Full Professor of the Graduate Course in Nursing of the School of Nursing of Botucatu (e-mail: sparada@botunet.com.br)
} 
area covered by this Healthcare Center, the basic healthcare unit located in the peripheral region of the municipality, quality prenatal care. Therefore, nursing consultations are developed as recommended by the Ministry of Health: monthly clinical visits up until the $32^{\text {nd }}$ week of gestation, every two weeks between the $32^{\text {nd }}$ and $36^{\text {th }}$ weeks, and weekly visits after the $36^{\text {th }}$ week of pregnancy.

Besides nursing consultations, the pregnant women go through two routine medical consultations, one at the beginning of the pregnancy, not necessarily the first visit, and the other at the end of the pregnancy, close to the $32^{\text {nd }}$ week of gestation. Additionally, if during the prenatal visits any risk is identified, the pregnant woman is immediately referred to a medical consultation or to a larger, more complex institution, depending on the seriousness of the case. Those who participate in it are a nurse, a full professor of the Graduate Nursing Course, and the two tocogynecologists of the Unit, who rotate in seeing these patients. As to the participation of the nursing team, it is still small and is carried out by pre- and post-consultations. The first clinical visit is conducted by the nurse, who takes the medical history, performs the general and obstetric physical examination and collects a sample for the Papanicolaou test, orders routine prenatal tests, and gives necessary orientation. If the pregnant woman is classified as low-risk, she is enrolled in the Program and her next visit is scheduled. In order to develop this project, some obstacles needed to be overcome. The primary hindrance was in reference to acceptance, on the part of medical professionals, laboratory directors, healthcare administrators, and others, of the fact that this activity was being performed by an obstetric nurse. We point out, however, that we assumed that the greatest resistance would come from the patients, which did not happen at any time. In addition, when we initiated the Program, there was no tocogynecologist at the Unit, and the gestants were referred for their medical consultations to the Regional Specialties Outpatient Clinic located in the central area of the city. The initiative is also important from the social point of view, not only due to the number of pregnant women seen, but also due to the quality with which it is carried out. In order to assess is coverage, we state that, in 1997, approximately $60 \%$ of the women who lived in the area covered by the Municipal Healthcare Center of Jardim Peabiru and who gave birth, had done their prenatal program at this center. Additionally, most of them had initiated their prenatal care early in the pregnancy, and had participated in six or more clinical visits, as is recommended by the Ministry of Health in order to consider a prenatal program effective."

As we can see, there are different types of problems indicated by the author for the performance of prenatal care by the nurse, and these reasons raise some hypotheses:

A - Is there a lack of technical preparation of nursing professionals for these tasks?

The family healthcare teams, which require the presence of a nurse in their composition, do not require that this professional is specialized or legally qualified in obstetrics, and these tasks are performed by general nurses, with little experience and without the necessary qualification in this specific area. Even those who are legally certified have acquired this title through curricular courses or lato sensu post-graduate courses, with insufficient learning class hours for giving adequate care to the prenatal, labor, and puerperium periods. The Magazine of São Paulo Regional Council of Nursing (COREN SP), $\mathrm{n}^{\circ} 73$, of 2008, describes this reality, pointing out failures in training of nursing professionals and the unsatisfactory results in their work.

B - Is there a lack of knowledge of this professional and of the physician as to the legal attributes of the obstetric nurse?

Leal et al., in the municipality of Palmas (TO), in a study of 25 nurses with less than one year of experience working in a PSF concluded:

"Most of the participants in the study are ignorant of the legislation and attributes of their trade associations. At the same time, the professionals do not feel secure enough to explore their potential and exert their functions fully, going against some legal limits. With these results, we perceive that there is no full exercise of these PSF nurses in the municipality of Palmas, which represents $73 \%$ of all nurses who work in the PSF of this city. With this, we conclude that the solution to the problems of the population cared for by these nurses has a lower degree of problem-solving capacity and efficacy, diminishing the dynamics of the PSF team, and if the nurse does not know about the extent of his/her responsibilities, the members of the team who coordinate and supervise the nurse know even less, which leads to misunderstandings and misguided information." ${ }^{(9)}$. 
In the same way, Araújo and Oliveira, in a study related to the view of physicians as to the activities of the obstetric nurse in an Obstetric Center, concluded that there is difficulty in accepting the role of the obstetric nurse on the part of the medical team. The lack of knowledge as to the legislation that regulates the activities of the obstetric nurse is, without a doubt, a problem that transcends questioning on the part of physicians $^{(10)}$.

C - Are the limits of rights and responsibilities of the obstetric nurse in the PSF known by administrators and responsible technicians at the UBS?

This question cannot be a cause for limiting the activities of the obstetric nurse in the UBS, since managers and technicians, whether of the healthcare area or not, have the obligation of knowing the law. Despite the positions of State and Municipal Healthcare Secretaries, the final managers of these processes, resulting from political ties and not technical qualifications, these administrators have the obligation of knowing the law or of finding aides that are technically able, and therefore, who know the law.

D - Are there conflicts of interest that generate disputes for the work market between obstetric nurses and physicians, since the prenatal consultation may be defined as a medical act?

Yes, there are conflicts of interest related to the activities of obstetric nursing, both as to disputing a place in the job market, and related to the medical training of the physician, who sees obstetric activity as a technical job that, therefore, must be considered as a medical act. An example of this conflict is seen in the text of the interview of the NGO "Friends of the Birth" (http://www.amigasdoparto.org.br) with the Obstetric Nurse Míriam Rêgo de Castro Leão, on May 8, 2006, who responded to the question formulated in the following way:

"How is the role of obstetric physicians seen within the work team? They are very resistant to change and fear losing their space. They generally feel more important than the other professionals on the team, and are authoritarian. Nevertheless, they are valuable partners; the obstetric nurse always works within a team, since even in home births, he/she relies on having a back-up physician for situations of complication."

Mello and Andrade describe the resistance that was faced in order for the nursing professional to assume the conduction of prenatal visits in a town in the state of Minas Gerais, reporting that the decision of the Municipal Administrator in maintaining this attitude, despite resistance of the physicians and of the local population, resulted in true benefits ${ }^{(11)}$.

The Normative Resolution $\mathrm{n}^{\circ} 167$, of 2008 , regulates and furnishes rights to patients of having their birth assistance carried out by an obstetric nurse, including supplementary healthcare plans, enabling both the care and the corresponding fees to be attributed to the nurse. This fact clearly creates a competition for the job market, since financial gains are thus directed toward the non-physician professional within a large number of deliveries that are continually happening.

\section{DISCUSSION}

The nursing consultation is the act of consulting or requesting an opinion or guidance. It is also a relationship of giving help and a situation for learning between the client and the nurse, in search of solutions for the problems of well-being that have been identified.

A series of topics proved necessary for the full exercise of this nursing professional, resulting in benefits for the clientele, complete professional fulfillment of the nurse, recognition of his/her work, full use of the nurse's rights within the healthcare system, and benefits to the healthcare system itself and to society, which profits and reaps the fruit of the investments made for the nurses' training.

These topics trigger actions such as:

- Intensification of the discussion on the current minimum curriculum of nursing, not only with the professors, taking into consideration CNE/CES Resolution $\mathrm{n}^{\circ}$ 3, dated November 2001, and also the opinion of the professionals who are active in healthcare and deal directly with the deficiencies, thus constructing a new and more contextualized curriculum. In this sense, the increased working hour load based on the theory that it is about ethics, as well as the constant discussion of legislation and professional ethics are essential.

- Continued education events, carried out by COFEN/ COREN, which discuss themes about professional ethics and legislation in nursing, facilitating a greater access of nurses to this system.

- Promotion and encouragement, on the part of ABEn, of scientific discussion groups, as well as the participation of nurses in scientific events as participants, reporters of scientific studies, and lecturers; performance of periodic diagnoses of the deficiencies of the nurses who work in the PSF in order to implement a system of continued training, allowing the exchange of experiences and the resolution of these deficiencies;

- Formulation of a plan for the development of human resources, involving managers (municipal and 
statewide), integrating ABEn and COFEN/COREN, with the intent of optimizing the intellectual capital of the nursing class, so the PSF nurse may develop his/her professional activities efficiently, effectively, and fully.

The obstetric nurse, with legal certification, necessary training, and availability should be universally included in giving low-risk prenatal care in the UBS and PSF, since they are nurses trained to treat healthy people (or who feel healthy - a characteristic of most pregnant women) and to accompany them during the progression of the pregnancy. Additionally, the nurse with specific scientific knowledge as to gravidic modifications is qualified to differentiate between what is normal and what is pathological. The training for preventive care and promotion of health - a mission of the primary level of healthcare, different from that of the physician, who is trained to identify and treat illnesses - makes this professional indispensable in normal prenatal activities. This affirmation reiterates the implementation of assistance to normal deliveries with no dystocia, performed by an obstetric nurse, which is already disseminated in our midst.

Locations where the physician's activities are limited, whether due to the inexistence of the profession, to limitations in the hours of work of the physician or to exiguous commitment of the medical professional with such activity, are fertile areas for the nurse to be active. It is evident that the encounter of abnormalities, identified by the obstetric nurse, should have reference mechanisms for necessary (medical) assessment, when the professional specialized in medical pathology comes on the scene.

In the same way, the activities of the obstetric nurse are performed during puerperium, when his/her training will provide education and orientation about this period and the essential support, incentive, and guidance regarding breastfeeding.
The universal insertion of the obstetric nurse in lowrisk pre-natal care in the UBS, which already exists in many counties, will certainly imply improved quality in prenatal care, satisfaction of the clientele, and maternal and perinatal benefits.

\section{CONCLUSIONS}

We conclude, therefore, that the activity of the nurse, conducting low-risk prenatal clinical visits in the basic public healthcare network, has legal and ethical support, and provides true benefits to the clientele.

\section{REFERENCES}

1. Geovanini T, Moreira A, Schoeller SD, Machado WC. História da Enfermagem: versões e interpretações. Rio de Janeiro: Revinter; 1995.

2. Silva TM. 0 saber dos médicos e o saber das parteiras [dissertação]. Rio de Janeiro: Universidade Rural do Rio de Janeiro, Instituto de Ciências Humanas e Sociais; 1999.

3. Almeida MC, Rocha JS. 0 saber da enfermagem e sua dimensão prática. São Paulo: Cortez; 1986.

4. Vargens OM. O homem enfermeiro e sua opção pela enfermagem [tese]. Ribeirão Preto: Universidade de São Paulo, Escola de Enfermagem; 1989.

5. Cruz AP. Curso didático de enfermagem - Módulo II. São Caetano do Sul (SP): Yendis; 2005.

6. Ziegel EE, Cranley MS. Enfermagem obstétrica. Rio de Janeiro: Guanabara Koogan; 1985

7. Osava RH, Tanaka AC. Os paradigmas da enfermagem obstétrica. Rev Esc Enferm USP. 1997;31(1):96-108.

8. Riesco ML. Que parteira é essa? [tese]. São Paulo: Universidade de São Paulo, Escola Enfermagem; 1999.

9. Leal DC, Monteiro EM, Barbosa MA. Os horizontes da percepção do enfermeiro do PSF sobre os limites de sua legislação. Revista de UFG [Internet]. [citado 2010 Jan 20]. Disponível em: http://www.proec.ufg.br/revista_ufg/familia/F_ horizontes.html

10. Araujo NR, Oliveira SC. A visão do profissional médico sobre a atuação da enfermeira obstetra no centro obstétrico de um hospital escola da cidade do Recife-PE. Cogitare Enferm. 2006;11(1):31-8.

11. Mello DF, Andrade RD. Atuação do enfermeiro junto à população maternoinfantil em uma unidade de saúde da família no município de Passos-MG. REME Rev Min Enferm. 2006;10(1):88-93. 